\title{
CHINA ECONOMIC UPDATE DECEMBER 2017
}

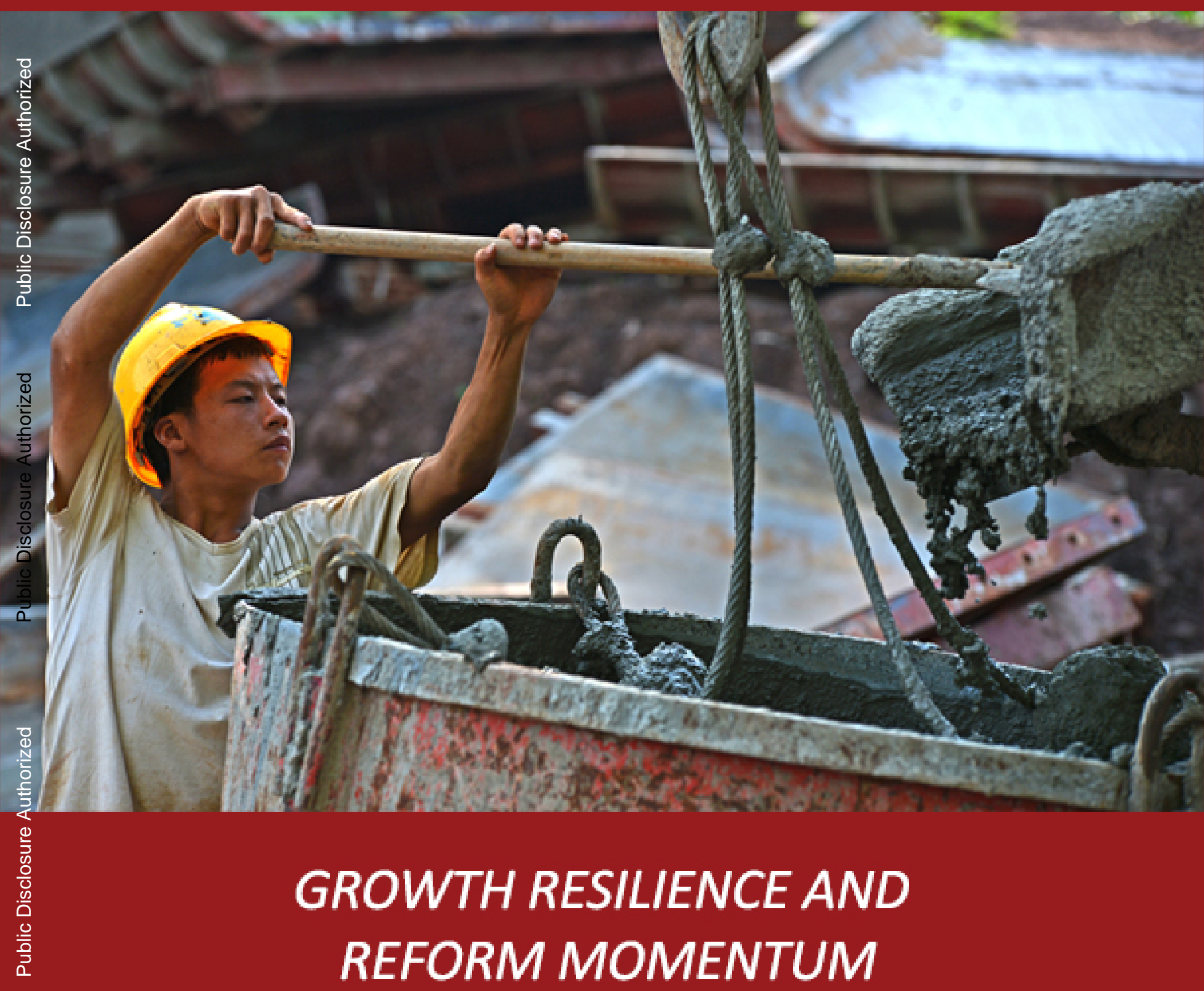





\section{Acknowledgements}

The World Bank Economic Update provides an update on recent economic and social developments and policies in China and presents findings from ongoing World Bank work on China. The Update was led by Elitza Mileva (Senior Economist) under the guidance of John Litwack (Lead Economist) and with contributions from Luan Zhao (Economist) on recent economic developments and outlook, John Litwack on budget reform, Mark Dorfman (Senior Social Protection Economist), Philip O'Keefe (Practice Manager, Social Protection and Labor Global Practice), and Dewen Wang (Senior Social Protection Economist) on pension system update. The team would like to thank Huitian Bai and Yunxia Chao for excellent research assistance. Helpful comments are gratefully acknowledged from Bert Hofman, Deepak Mishra, Sudhir Shetty, and Ekaterine Vashakmadze. The team would also like to thank Tianshu Chen, Li Li, Xiaoting Li, Lin Yang, and Ying Yu for support in the production and dissemination of this report. The findings, interpretations, and conclusions expressed in this report do not necessarily reflect the views of the Executive Directors of the World Bank or governments they represent. Questions and feedback can be addressed to Li Li (lli2@worldbank.org). 


\section{Table of Contents}

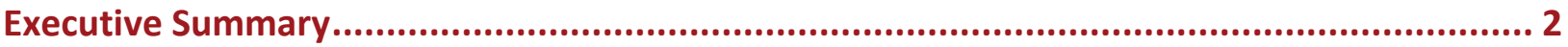

A. Recent Economic Developments and Outlook....................................................... 3

1. Growth remains resilient as macroeconomic policy is tightened ................................................

2. Trade improved and capital outflows declined amid a global recovery..........................................5

3. Tighter policy stance has led to some credit growth moderation .................................................6

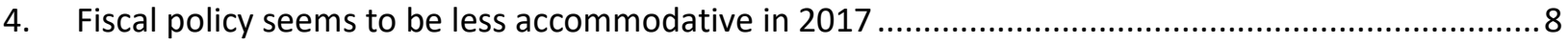

5. New jobs and income growth supported consumption-led rebalancing ........................................10

6. Deleveraging remains China's macroeconomic policy priority ........................................................10

B. Medium-Term Development Agenda............................................................ 13

1. Budget reform: Recent developments in subnational debt management....................................13

a. Three years of budget reform - initial results for debt management....................................13

b. Implementing budget reform will remain challenging but promises major benefits ...............16

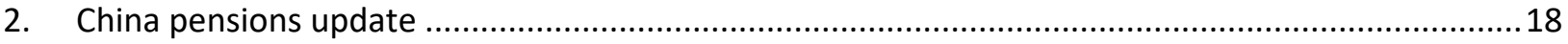

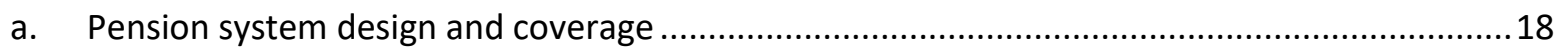

b. Reform challenges include coverage, system integration, and financial sustainability ............20

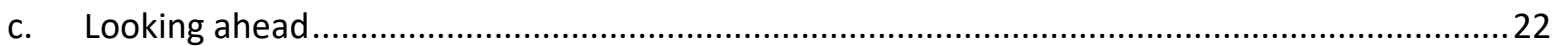

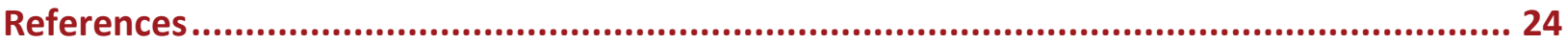




\section{Executive Summary}

GDP growth in China has remained strong in 2017, exceeding market expectations. Supported by rising household incomes, the growth contribution of final consumption increased further this year. At the same time, the growth contribution of fixed investment has declined notably. This was partly driven by government efforts to limit local government off-budget financing of public investment but also by weaker private investment.

The recovery in global trade has been an important factor supporting economic activity in China in 2017. Net exports contributed positively to growth for three consecutive quarters, compared to a negative contribution in 2015-2016. Owing to favorable global financial conditions, as well as stricter implementation of capital controls and greater domestic market confidence, capital outflows from China declined to US\$47 billion in the first three quarters of 2017, from US\$640 billion in 2016. The Renminbi appreciated by 5.0 percent against the US dollar over January-November 2017.

Since late 2016, the Government has introduced important measures to slow down the pace of leveraging in the economy. These include less accommodative monetary policy, new financial regulations, more comprehensive bank risk (including off-balance sheet) monitoring, improved monitoring of fiscal risks, and a stricter implementation of the 2014 budget reform. In response, growth in total credit to the nonfinancial sector moderated to 14.1 percent annualized in the first eleven months of 2017, compared to an average of 15.9 percent in 2016. More pronounced deleveraging has been observed in the non-bank financial market, including financing not covered by the credit numbers above. The pace of debt accumulation by local governments and local government financing vehicles (LGFVs) has also slowed down.

New reforms were also announced in the weeks following the $19^{\text {th }}$ Congress of the Communist Party of China (CPC) held in October. The authorities released guidance to further promote fair competition and set up a new intra-ministerial group on market supervision. A pilot program was established to transfer state assets to social security funds to address the pension financing gap. New initiatives were announced to strengthen the financial sector, most notably lifting caps on foreign ownership of financial institutions.

Two of the above-mentioned reform themes are the special focus of this report. Section B.1 documents the progress made in debt management as part of the on-going budget reform, which has brought important changes to local government budgeting, finance, and debt management. Important measures introduced in late 2016 and 2017 have addressed some of the earlier implementation issues. However, a number of challenges remain.

Section B. 2 takes stock of China's pension system reform which has achieved vastly expanded coverage in recent years but also faces several challenges. These include information constraints and limited portability across locations due to the system's very decentralized nature, rapid population ageing, limited benefits for most beneficiaries, a high cost to business from social taxes, and substantial legacy costs. Successful pension reform is critical to China's economic rebalancing and social transformation in the coming decades.

GDP growth is projected to decline from 6.8 percent in 2017 to 6.4 percent in 2018 and 6.3 percent in 2019, mainly because of domestic policy tightening. Prudent monetary policy, stricter financial sector regulation, and the Government's continuing efforts to restructure the economy and to reign in the pace of leveraging are expected to contribute to the growth moderation. Favorable economic conditions make this a particularly opportune time to further reduce macroeconomic vulnerabilities and pursue reforms that target 'better quality, more efficient, fairer, and more sustainable development,' as emphasized by President Xi during the 19th Party Congress in October. 


\section{A. Recent Economic Developments and Outlook}

\section{Growth remains resilient as macroeconomic policy is tightened}

Exceeding market expectations, GDP increased by 6.9 percent year-on-year (yoy) in the first half of 2017 and by 6.8 percent in the third quarter. Economic activity was sustained by domestic consumption and improving external conditions (Figure 1.1a). A deceleration in investment growth has supported gradual economic rebalancing. Monetary and regulatory tightening have weighed on economic activity in construction, real estate, and financial services in recent quarters, but industry and other service sectors have supported growth.

Final consumption, which contributed 4.5 percentage points to growth in the three quarter of 2017 relative to the same period in 2016, continues to support domestic rebalancing away from investment. After bottoming out in Q3 2016, growth in average real household income accelerated to 7.5 percent yoy in Q1Q3 2017, exceeding GDP growth and boosting household consumption. Consumer sentiment, as measured by the National Bureau of Statistics' (NBS) Consumer Confidence Index, has improved by more than 15 points since December 2016 to 123.9 in October 2017.

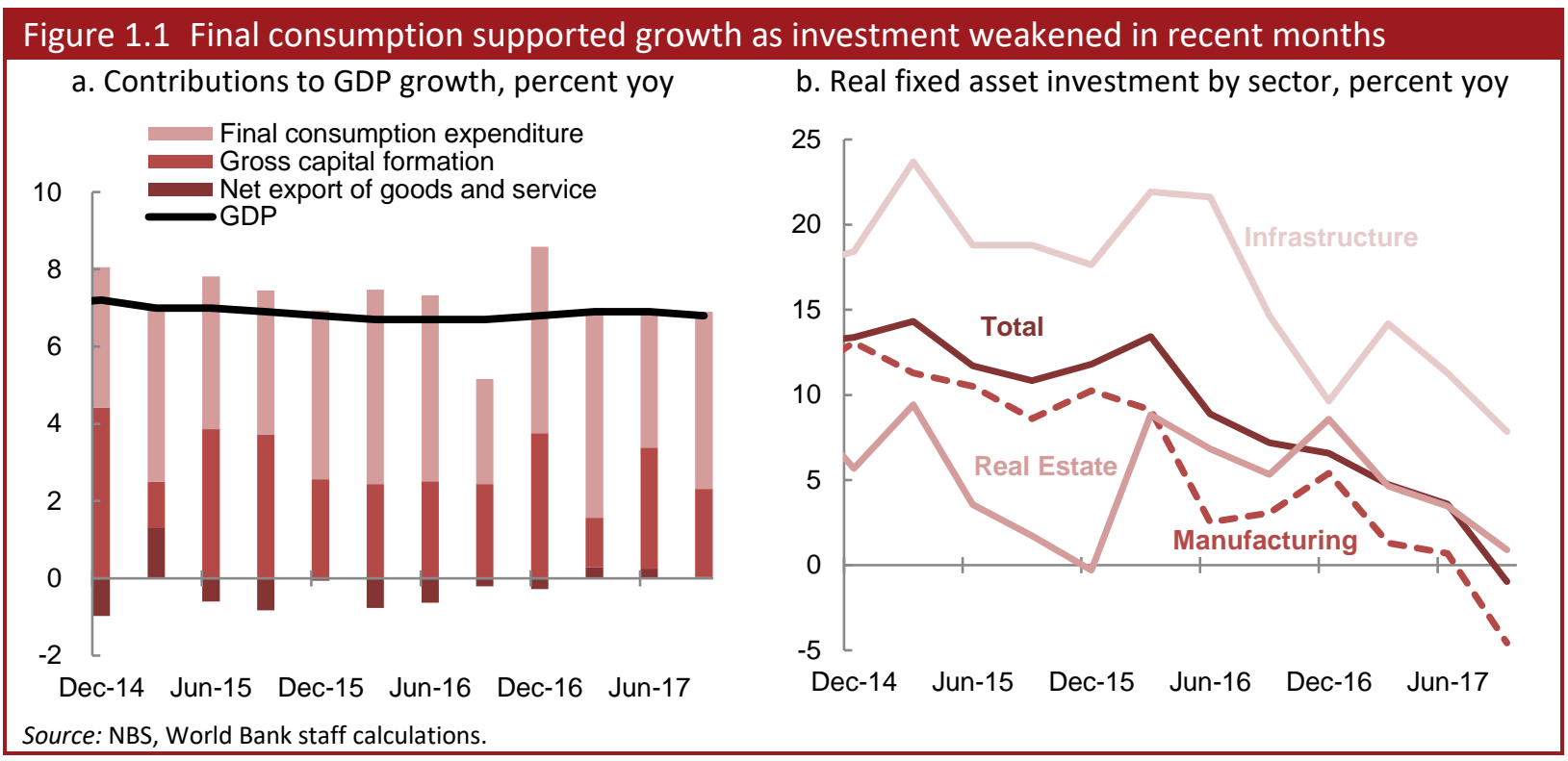

The growth contribution of investment fell to 2.3 percentage points yoy in the three quarters of 2017, compared with 2.8 percentage points in 2016. The recent deceleration in gross capital formation tracks the declining trend in real fixed asset investment (FAI) growth (Figure 1.1b). ${ }^{1}$ Real FAl declined by 1.0 percent yoy in Q3 2017, compared with average growth of 4.2 percent in the first half of 2017. After weak growth in the first six months, investment spending in the manufacturing sector declined by 4.6 percent in the third quarter compared with the same quarter in 2016. Infrastructure FAI growth decelerated from an average of 12.7 percent yoy in $\mathrm{H} 12017$ to 7.8 percent in Q3 2017, which likely reflects government efforts to limit bank-financed off-budget public investment. FAl in real estate, which supported growth in 2016, has also weakened considerably. By ownership, real FAl growth moderated to 2.8 percent yoy in the state sector and turned negative, at -3.1 percent, in the private sector in Q3 2017 (see Box 1.1). FAl growth

\footnotetext{
1 Often used as a proxy for gross fixed capital formation in the national accounts, FAl differs from it in several ways. For example,
} it includes spending on second-hand assets and land acquisition costs and excludes spending on research and development. 
weakened further in October 2017, to an estimated -1.2 percent yoy in real terms, with a slowdown observed across sectors.

\section{Box 1.1 Why is private investment growth weak?}

Real FAl growth decreased significantly to 2.0 percent yoy in the first three quarters of 2017, down from 14.5 percent in 2014. The slowdown has been most pronounced for private enterprises (Figure 1.2a). The trend of declining real FAI growth in the private sector began in 2012. However, the weakening in private investment growth since the end of 2015 has been particularly sharp and persistent. Private firms spent only 0.3 percent more on FAl in real terms in the first nine months of 2017 relative to the same period in 2016.

\section{Figure 1.2 Investment growth has continued to decelerate, particularly for private firms}

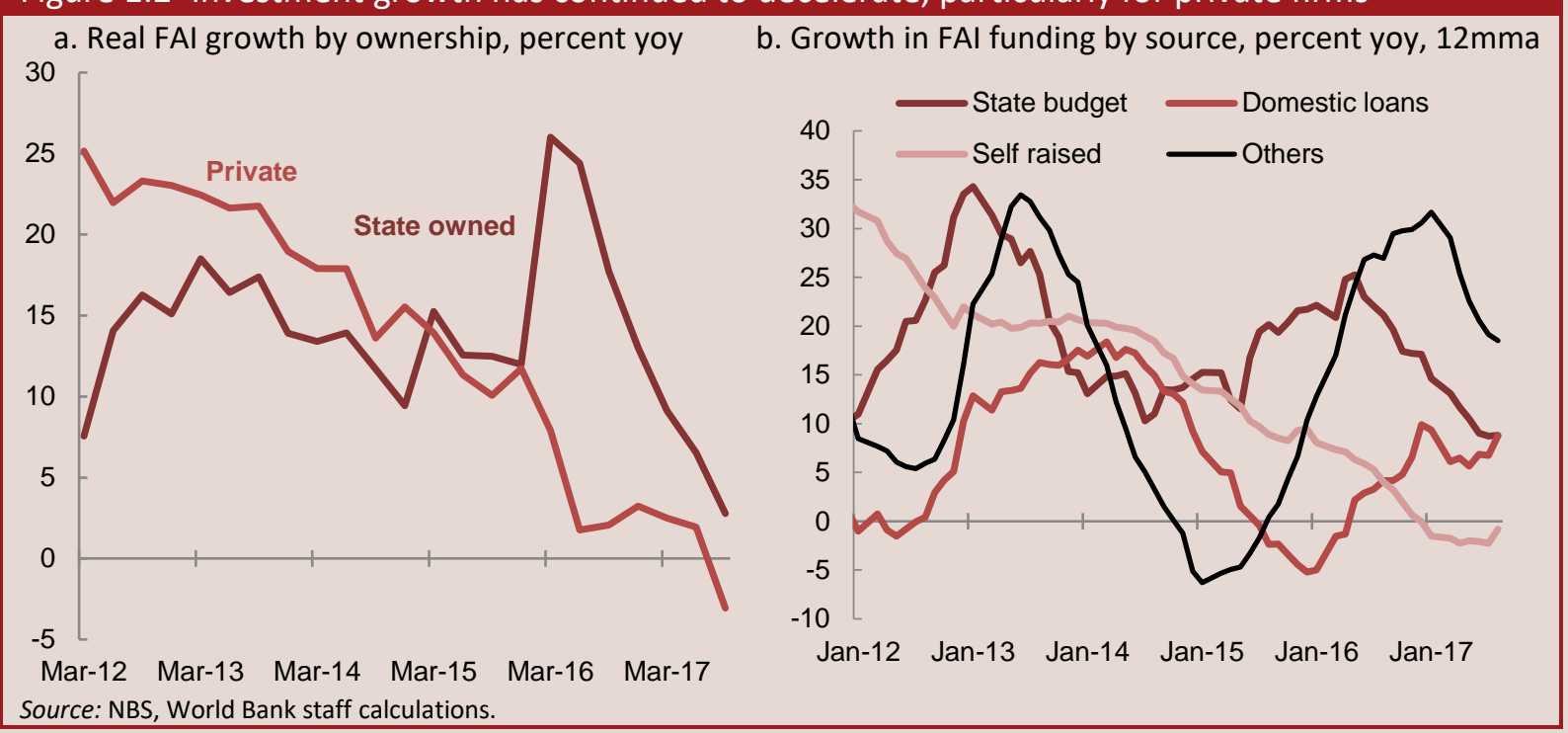

One possible explanation of the private investment slowdown is limited financing. Firms in China, especially private ones, rely mainly on internal financing for investment. According to NBS data, in 2016 two thirds of total FAl was financed by "self-raised funds". In manufacturing, which is dominated by private firms, 90 percent of FAI was financed by self-raised funds. Domestic loans provided only 11 percent of total FAl financing.

Growth in self-raised funds decreased considerably after 2012 and turned negative in December 2016. Given that retained earnings are a major source of self-raised funds, declining enterprise profits to a large extent explain that drop. However, in 2017 private sector profits improved, rising by an average of 14.5 percent yoy in January-September 2017, while the self-raised funds used for FAl continued to decline. This suggests private firms have been reluctant to reinvest retained earnings.

There is also little evidence that the lack of external financing has constrained private investment growth in recent quarters. Despite the tightening in overall financing conditions since late 2016, domestic loans grew at a steady pace (see Section 3). Domestic loans as an FAl financing source grew by 8.6 percent yoy in the first three quarters of 2017, down slightly from 9.9 percent in 2016 (Figure 1.2b).

Hence, the firms' reluctance to undertake new investments appears to be an important reason for the recent slowdown in private FAI growth. The hard-data evidence stands in contrast to the steadily rising business sentiment, as measured for instance by the purchasing managers' indices, in recent months. 
From the production perspective, recent government policies can be associated with lower growth contributions of construction, real estate, and financial services this year (Figure 1.3a). Less accommodative monetary policy, stricter financial sector oversight, tighter macroprudential measures on mortgage lending in larger cities, and efforts to encourage local governments toward more prudent public finance have helped shift the composition of growth toward industry and other service sectors. Among industrial sectors, real value added in mining has declined in most months since April 2016, driven by the authorities' policies to reduce excess capacity in coal and steel (Figure 1.3b). Instead, industrial growth has been supported by a pickup in manufacturing growth, in particular in high-tech sectors.

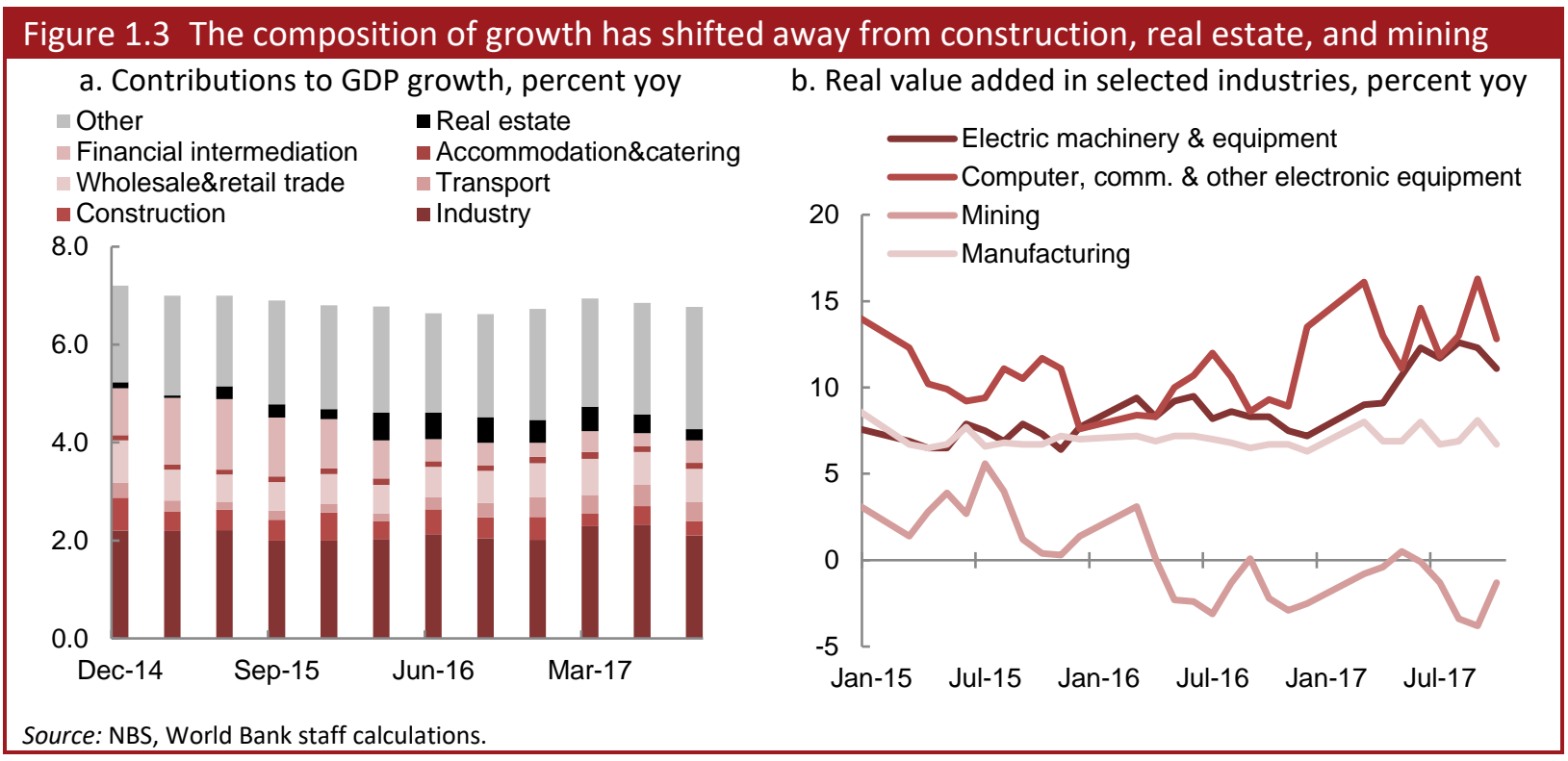

Consumer price inflation has remained low because of persistent food price deflation, while rising producer prices have supported a recovery in industrial profits. In the first eleven months of 2017, consumer prices increased by an average of 1.5 percent yoy compared with a target of 3 percent. Food prices declined by 1.9 percent yoy, on average, between February and November 2017. On the other hand, producer prices rose by an average of 6.5 percent yoy, compared with a decrease of 1.4 percent in 2016. Strong price increases in mining and raw material processing have helped boost profits in upstream industries.

\section{Trade improved and capital outflows declined amid a global recovery}

The global economy has experienced a broad-based recovery in 2017, with a rebound in world trade flows and favorable financial conditions. Economic activity has improved in recent quarters in both advanced and developing countries and the World Bank expects global growth to average 2.9 percent in 2017-2019 (World Bank, 2017). World trade growth has gained momentum and is forecast to increase by about 4 percent in the near term, compared with 2.3 percent in 2016. Global financial conditions have remained benign on account of an improving global outlook, positive investor sentiment, and persistently low foreign borrowing costs despite expectations of further monetary policy normalization in advanced countries.

The recovery in global trade has supported China's economy, with net exports contributing 0.2 percentage points to GDP growth in Q1-Q3 2017, compared with -0.5 percentage points in 2016. In the first three quarters of 2017, the US dollar value of exports of goods and services increased by 9.4 percent over the same period in 2016. In contrast, total exports contracted by 6.9 percent in 2016. According to customs trade data, among China's major industrial export categories, mechanical and electrical equipment and high-tech products recovered strongly from last year. The imports of goods and services rose by 15.4 
percent yoy in the first three quarters of 2017, compared with a decline of 2.7 percent in 2016 . The rebound in import growth was driven to largely by higher commodity prices in 2017 . The current account balance narrowed further to USD 106.4 billion or 1.2 percent of GDP in January-September 2017, down from 1.8 percent in 2016 (Figure 1.4a).

\section{Figure 1.4 Capital outflows have declined sharply and the Renminbi has appreciated against the US} dollar

a. Components of the balance of payments, USD billion

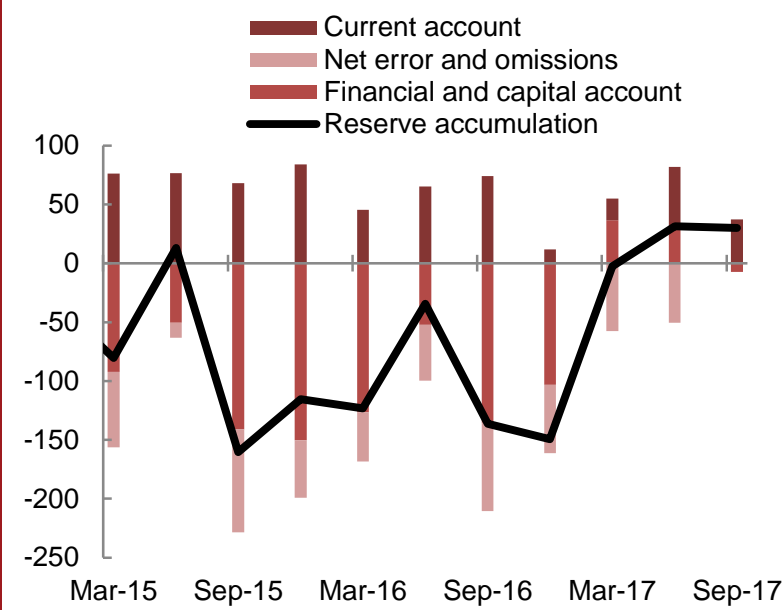

b. Renminbi exchange rates, indices

(December 31, 2014=1)

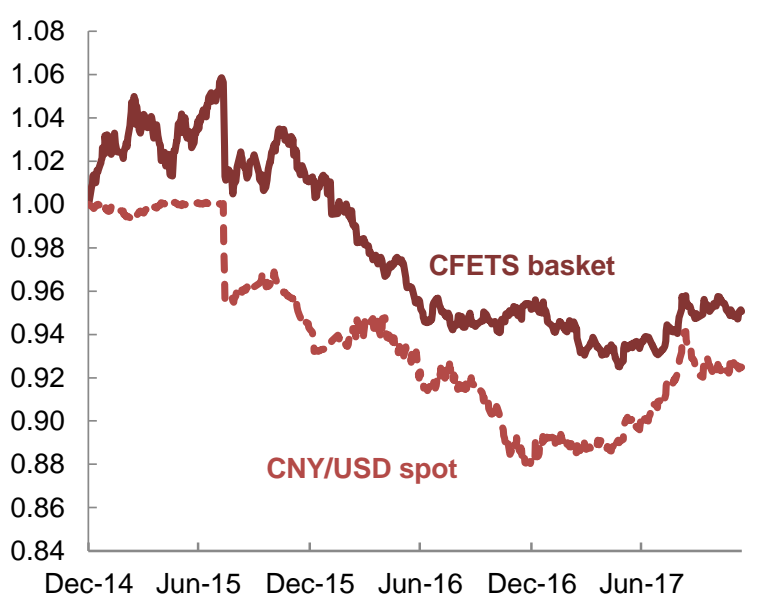

Source: PBOC, SAFE, World Bank staff calculations.

Owing to stricter enforcement of capital controls and greater market confidence, capital outflows from China fell and the Renminbi appreciated against the US dollar in 2017. Year to date, gross foreign exchange reserves increased by US\$109 billion to US\$3.12 trillion in November, compared to a loss of US\$320 billion in 2016. Net capital outflows, mostly recorded as errors and omissions, declined to US\$47 billion in the first three quarters of 2017, down from US\$479 billion in the same period in 2016. Curbs on capital outflows significantly reduced outbound direct investment, with FDI outflows falling from US\$181 billion in Q1-Q3 2016 to US\$65 billion Q1-Q3 2017. Inbound FDI also continued to weaken from US\$171 billion in the first three quarters of 2015 to US\$101 billion in the same period in 2016 to US\$86 billion in Q1-Q3 2017. In the context of broad US dollar depreciation, the Renminbi appreciated by 4.8 percent against the US dollar and remained stable against the trade-weighted basket of currencies in the year until December 12, 2017 (Figure 1.4b).

\section{Tighter policy stance has led to some credit growth moderation}

Since late 2016, the People's Bank of China (PBOC) tightened monetary policy through reduced liquidity provision and higher policy rates. The central bank injected RMB 1.4 trillion in the first three quarters of 2017, compared with RMB 4.1 trillion during the same period of 2016 (Figure 1.5a). At the start of 2017, the PBOC also raised the policy rates of its various liquidity facilities, while keeping the benchmark lending and deposit rates unchanged (Figure 1.5b). Both interbank rates and bond yields have increased in response to the tighter policy stance. In October and November 2017, government bond yields climbed to their highest level in more than three years, 4.0 percent on November 23, as market expectations of a stepped-up government effort to reduce financial sector leverage rose. Interest rates stabilized after the central bank provided large liquidity injections over this period. 


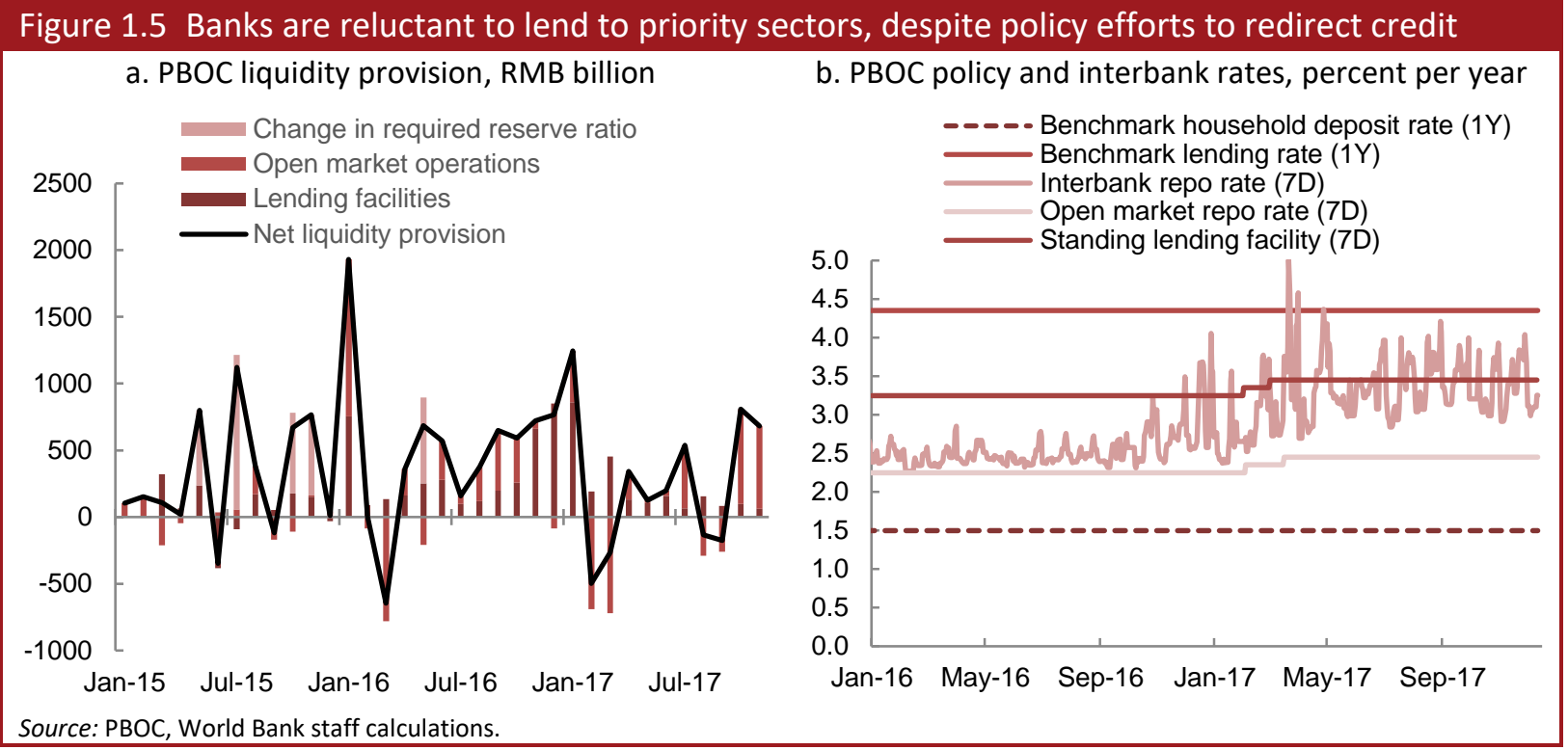

Tighter monetary conditions were complemented by regulatory measures aimed at lowering financial risks. Commercial banks were obliged to limit the stock of wealth management products (WMPs) invested in assets other than stocks and bonds to below 4 percent of total assets and 35 percent of outstanding WMPs. In addition, negotiable certificates of deposit are now classified as interbank borrowing, which is capped at 33 percent of total liabilities. ${ }^{2}$ Other measures include more comprehensive and frequent monitoring of bank sector risks (including those off-balance sheet), the creation of "mutual assistance funds" to mitigate liquidity risks, ${ }^{3}$ the promotion of creditor committees in restructuring debt, and the establishment of a State Council Financial Stability and Development Commission to improve regulatory coordination. ${ }^{4}$

In this policy context, the pace of credit growth has moderated in 2017, in particular for the corporate sector. Total credit to the non-financial sector increased at an annualized pace of 14.1 percent in the first eleven months of 2017, compared to 15.9 percent in 2016 (Figure 1.6a). If adjusted for the effect of the local government debt swap program, corporate loans account for most of the credit growth slowdown. The debt swap was introduced in 2015 to transform LGFV bank loans into municipal bonds to reduce the debt burden of LGFVs. If the debt swap amounts are added back to total bank loans to non-financial corporations (RMB 4.9 trillion in 2016 but only an expected RMB 3 trillion in 2017), the adjusted growth rate is 2.8 percent annualized in the first ten months of 2017, compared with 8.5 percent in 2016. Among the components of non-bank financing, the growth in the stock of entrusted loans and corporate bonds has declined sharply in 2017.

Stricter regulation helped reduce the stock of commercial bank WMPs by 2 percent in mid-2017 relative to December 2016. This compares to the rapid growth in the stock of WMPs of 56.5 and 23.6 percent in 2015 and 2016, respectively. The decline in bank funding through WMPs was reflected in slower expansion of commercial bank assets. In the first ten months of 2017, the assets of smaller city and joint-stock banks increased at an annualized rate of 5.9 percent compared to 20.0 percent in 2016. A sharp decline in investment receivables of smaller banks invested in asset management products (AMPs) of non-bank

\footnotetext{
2 In many countries, negotiable certificates of deposit are longer-term instruments similar to bonds. However, in China they have been used by banks largely for short-term interbank placements tied to short-term interest rates.

3 Provincial-level funds that allow banks to pool funds to cover potential liquidity shortfalls in individual banks.

${ }^{4}$ In November 2017, regulators released a draft new asset management product framework, unified across agencies, with stricter rules on disclosure, leverage, provision, and investment in non-standard assets, as well as a ban on payment guarantees among other new measures.
} 
financial institutions explains a portion of the asset growth slowdown. The moderation in asset growth was more modest for large banks: 7.0 percent annualized in the first ten months of 2017, down from 10.5 percent in 2016.

\section{Figure 1.6 Credit growth has decelerated and some non-bank financial markets are deleveraging}

a. Growth in credit to the non-financial sector, percent yoy

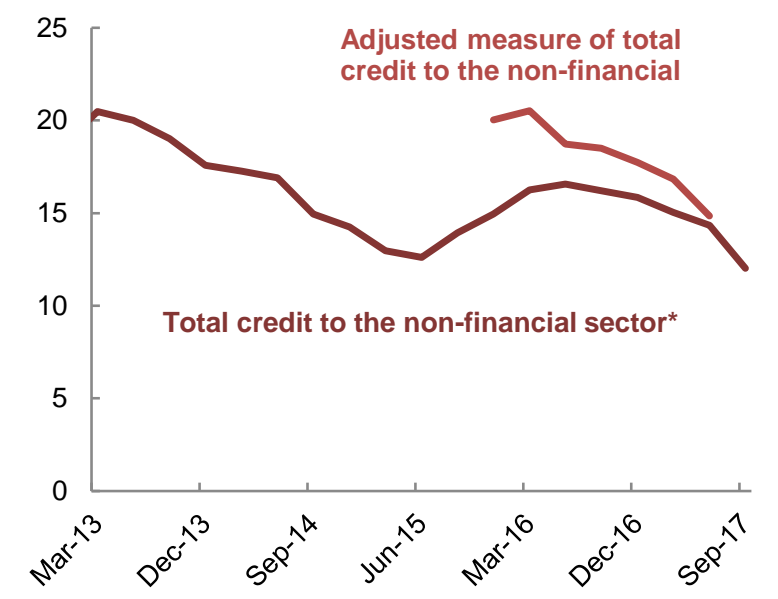

b. The stock of AMPs issued by non-bank financial institutions, percent of GDP

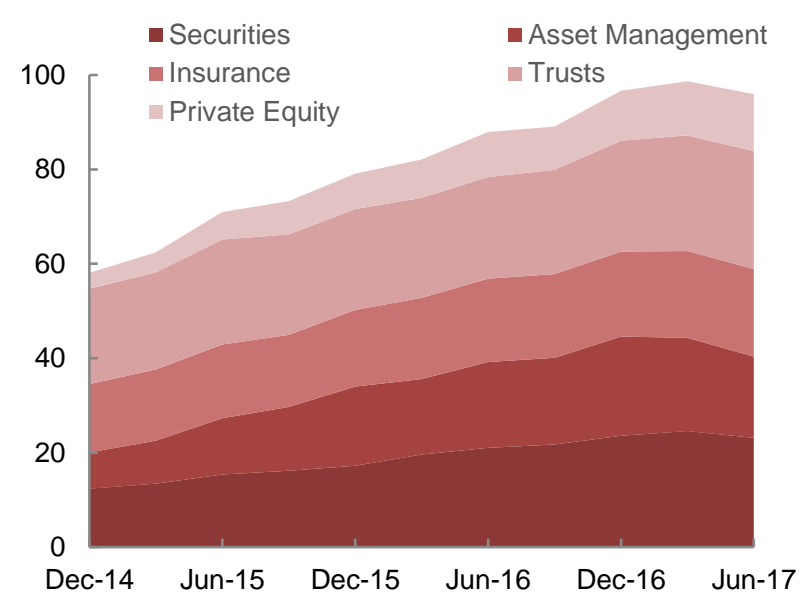

Note: * Total credit to the non-financial sector = Total social financing + general government bonds - equity financing. $* *$ The adjusted measure adds an estimate of AMP funds going to the non-financial sector.

Source: Asset Management Association of China, NBS, World Bank staff calculations.

More pronounced deleveraging has been observed in the non-bank financial market. The stock of AMPs issued by securities companies and asset management funds as a share of GDP declined (Figure 1.6b). As these financial institutions are highly reliant on bank financing, policy pressure on banks to reduce exposure to such AMPs has contributed to this deleveraging. A breakdown of AMPs by end use, released by the Asset Management Association of China, suggests that a large share of funds raised through AMPs go to the nonfinancial sector. If the estimated additional AMP funds going to the real economy is added to the official measure of total credit to the non-financial sector, then the slowdown in credit growth in 2017 would be more significant. Growth in credit to the non-financial sector by this adjusted measure was 20.5 percent in Q1 2016, slowed to below 18 percent by the end of 2016 and to around 15 percent by mid-2017 (Figure 1.6a).

\section{Fiscal policy seems to be less accommodative in 2017}

Revenues in the Public Finance Budget ${ }^{5}$ grew by 8.4 percent yoy in January--November 2017, up from 5.7 percent in the same period last year. Total tax revenues grew by 11.2 percent yoy, compared to 6.0 percent during the same period last year. Higher than expected revenue growth has been driven by stronger nominal consumption growth compared to last year, improved global import demand (affecting VAT and tariff revenues), and a surge in commodity prices (contributing to both higher tariffs and resource taxes). In the Government Fund Account, land-lease revenues increased by 33.6 percent yoy for the first eleven months of 2017, up from 19.1 percent in January-November 2016.

\footnotetext{
${ }^{5}$ China's budget system consists of (i) Public Finance Budget which includes tax and non-tax revenues, current expenditures, and a portion of capital expenditures; (ii) Government Fund Budget which reflects mainly land-lease revenues of local governments and expenditures for specific infrastructure and social projects; (iii) Social Security Fund Budget which records social insurance premiums, subsidies, and disbursements; and (iv) SOE Fund Budget which is the state-owned assets operation budget.
} 
With faster revenue growth and weaker expenditure growth, fiscal policy has become less expansionary in 2017. Expenditures in the Public Finance Budget (current spending plus some capital expenditures) grew by 7.8 percent yoy in the first eleven months of 2017, down from 10.2 percent in the same period in 2016. Although spending growth in the Government Fund Budget (mainly for specific infrastructure and social projects) accelerated in recent months, it has remained considerably below target. If one assumes a net contribution to the Stabilization Fund, local government special bond issuance, Social Security and StateOwned Enterprise (SOE) Fund net revenues equal to the Budget targets, then fiscal data through November point to a smaller adjusted (i.e., overall fiscal system) deficit of 2.6 percent of GDP, compared with 3.7 percent planned in the 2017 Budget and to 3.2 percent in 2016 (Table 1.1). Although overall government debt levels are manageable, there are still challenges related to local government debt sustainability (see Section B.1).

\begin{tabular}{|c|c|c|c|c|}
\hline & 2015 & 2016 & $\begin{array}{c}2017 \\
\text { Budget }\end{array}$ & $\begin{array}{c}\text { Jan-Nov } \\
2017\end{array}$ \\
\hline \multicolumn{5}{|l|}{ Public Finance Budget } \\
\hline Revenues & 16,027 & 16,682 & 17,106 & 16,175 \\
\hline Central government & 6,923 & 7,236 & 7,861 & 7,739 \\
\hline Local government (excludes transfers from central budget) & 8,298 & 8,719 & 9,002 & 8,436 \\
\hline Withdrawal from Stabilization Fund & 806 & 727 & 243 & \\
\hline Expenditures & 17,647 & 18,862 & 19,486 & 17,956 \\
\hline Central government (excludes transfers to local governments) & 2,555 & 2,740 & 2,960 & 2,567 \\
\hline Local government & 15,022 & 16,044 & 16,477 & 15,389 \\
\hline Contribution to Stabilization Fund & 70 & 78 & 50 & \\
\hline Fiscal balance & $-1,620$ & $-2,180$ & $-2,380$ & $-1,781$ \\
\hline Fiscal balance (\% of GDP) & -2.4 & -2.9 & -2.9 & -2.2 \\
\hline \multicolumn{5}{|l|}{ Government Fund Budget } \\
\hline Revenues & 4,399 & 5,087 & 5,547 & 4,931 \\
\hline Land-lease revenues & 3,255 & 3,746 & & 4,139 \\
\hline Local government special bond issuance & 100 & 400 & 800 & \\
\hline Net withdraw from Stabilization Fund & 66 & 25 & 30 & \\
\hline Expenditures & 4,236 & 4,685 & 5,547 & 4,619 \\
\hline Social security net revenue & 524 & 435 & 334 & \\
\hline SOE Fund net revenue & 48.2 & 43.0 & 37.7 & \\
\hline Adjusted fiscal balance* & $-1,786$ & $-2,374$ & $-3,032$ & $-2,121^{* *}$ \\
\hline Adjusted fiscal balance (\% of GDP) & -2.6 & -3.2 & -3.7 & $-2.6^{* *}$ \\
\hline \multicolumn{5}{|c|}{$\begin{array}{l}\text { Note: }{ }^{*} \text { The adjusted fiscal balance = Public Finance Budget balance + Government Fund Budget balance + Social security and SOE Fund } \\
\text { net revenues - Net contribution to Stabilization Fund. }{ }^{* *} \text { The estimated adjusted balance for Jan-Nov } 2017 \text { assumes a contribution to the } \\
\text { Stabilization Fund, local government special bond issuance, Social Security and SOE Fund net revenues equal to the Budget targets. } \\
\text { Source: Ministry of Finance, World Bank staff calculations. }\end{array}$} \\
\hline
\end{tabular}




\section{New jobs and income growth supported consumption-led rebalancing}

China's economic resilience has been reflected in relatively high job creation and rising incomes. In the first three quarters of this year, almost 11 million new urban jobs were created, compared with 10.7 over the same period in 2016. Growth in real income per capita in both urban and rural areas has also picked up. In contrast to 2016, growth in real average disposable income, at 7.5 percent yoy in the first three quarters of 2017, is again faster than growth in real GDP (Figure 1.7a).

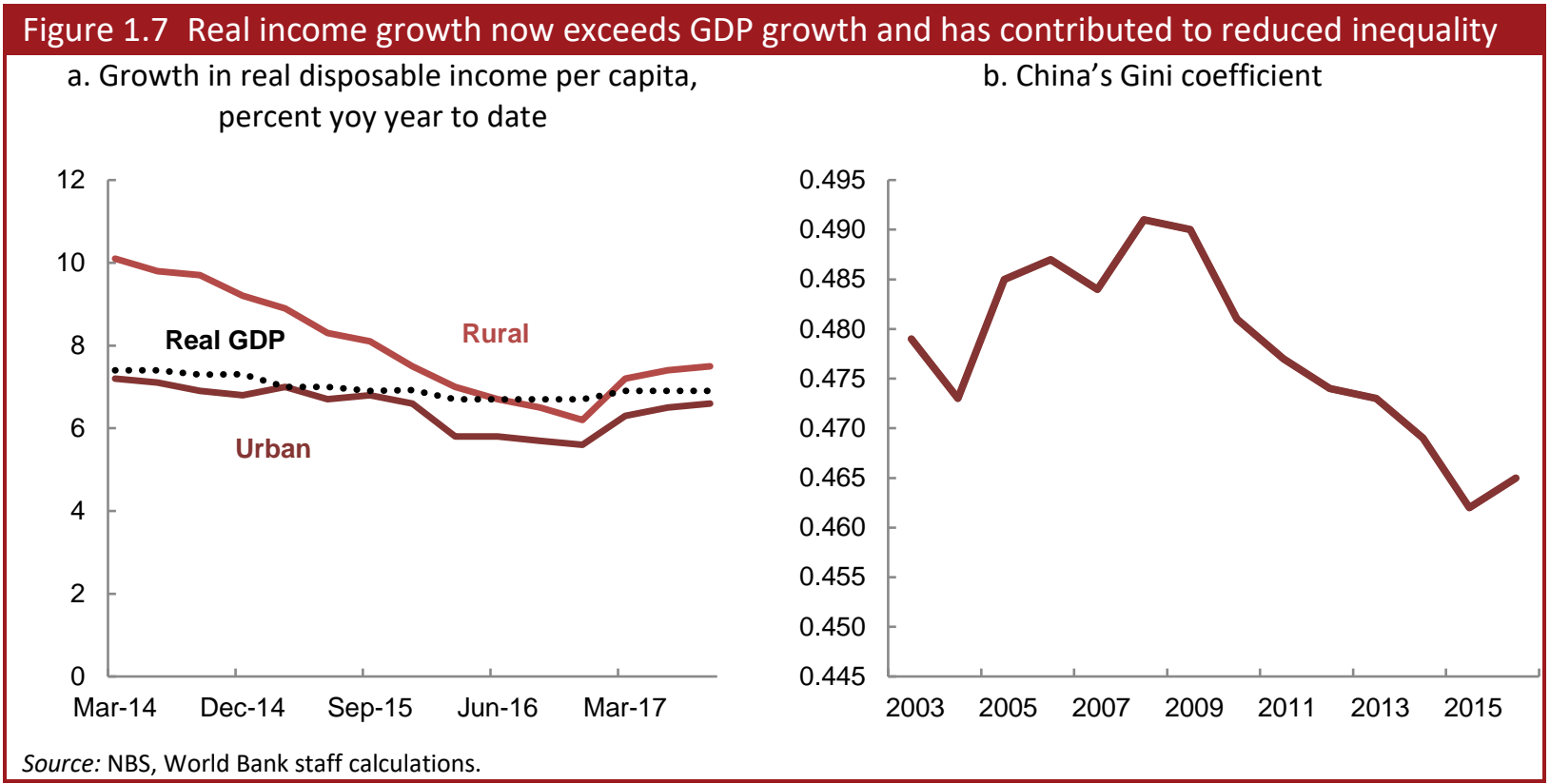

Robust household income growth is necessary for economic rebalancing and rising rural incomes have been linked to lower inequality. Faster growth in disposable incomes would contribute to the shift from reliance on investment toward household consumption. In addition to rebalancing, faster income and consumption growth in rural relative to urban areas in recent years has decreased the urban-rural income gap. Research points to this development as the main reason behind the recent reduction in inequality in China (World Bank, 2017). According to NBS data, the Gini coefficient, a measure of inequality, declined from a peak of 0.491 in 2008 to 0.465 in 2016 (Figure 1.7b).

\section{Deleveraging remains a key macroeconomic policy priority}

Despite exceeding market expectations in the first three quarter of 2017, GDP growth is still expected to slow down in the near term, mainly on account of domestic policy tightening. GDP growth is projected at 6.8 percent in 2017, declining to 6.4 percent in 2018 and 6.3 percent in 2019 (Table 1.2). Consumption will remain the main driver of growth on the demand side. Less accommodative monetary policy, stricter financial sector regulation and the Government's continuing efforts to restructure the economy and reign in credit growth are expected to contribute to this growth moderation.

The key downside risk to the outlook is related to the still rising, albeit at a slower pace, leverage of the nonfinancial sector and uncertainty related to property prices. Despite the recent slowdown, credit continues to grow considerably faster than GDP. Outstanding bank loans reached 150 percent of GDP in November 2017, up from 103 percent at the end of 2007. Total credit to the non-financial sector, including central and local government, was 242 percent of GDP in November 2017, about 100 percent higher than before the global financial crisis. House price growth, as measured by NBS's 70-city index, moderated from 10.4 percent yoy in Q4 2016 to 7.9 percent in Q3 2017 and 5.6 percent in November. A sharper slowdown in 
property price growth is likely to weigh on household consumption (through a wealth effect) and on the construction and real estate sectors.

The economic resilience of recent quarters offers the authorities an opportunity to accelerate deleveraging. Reducing fiscal and financial vulnerabilities is likely to come at the cost of slower GDP growth in the near term but will improve China's long-term economic prospects. As demonstrated throughout 2017 and during the $19^{\text {th }}$ Congress of the Communist Party of China, financial stability has become a top policy priority for the authorities. Careful liquidity management and further regulatory tightening will be essential in mitigating the risk of possible cases of financial distress becoming a larger problem.

Despite recent improvement in the international environment, there are also external risks to China's outlook. These stem from the possibility of more restrictive trade policies in advanced countries and heightened geopolitical tensions. The uncertainty associated with the withdrawal of accommodative monetary policies in high-income economies may contribute to less favorable global financing conditions for emerging markets, which could affect China through lower net capital inflows or through reduced exports to developing countries, though the direct trade impact on China is likely to be small.

To limit external risks China could enhance further its trade, investment, exchange rate and capital control policies. China has already seized on the opportunity to play a leading role in defending world economic integration and trade, including through such regional trade arrangements as the Regional Comprehensive Economic Partnership and the Belt and Road Initiative. That role will be further enhanced to the degree that China accelerates opening up sectors hitherto closed for foreign and private investors (as with the recently announced higher caps on foreign ownership of financial institutions). The negative impact of higher US interest rates on capital flows could be mitigated by enhancing the clarity of exchange rate and capital control policies.

\section{Table 1.2 GDP growth is expected to decelerate modestly in 2018-2019}

\begin{tabular}{|c|c|c|c|c|c|c|}
\hline & 2014 & 2015 & 2016 & $2017 f$ & $2018 f$ & $2019 f$ \\
\hline Real GDP growth, at constant market prices (percent) & 7.3 & 6.9 & 6.7 & 6.8 & 6.4 & 6.3 \\
\hline Final consumption (contribution to growth, percentage points) & 3.6 & 4.1 & 4.3 & 4.4 & 4.1 & 4.1 \\
\hline Gross fixed capital investment & 3.2 & 3.0 & 2.9 & 2.4 & 2.3 & 2.3 \\
\hline Net exports & 0.6 & -0.2 & -0.5 & 0.1 & -0.1 & 0.0 \\
\hline Real GDP growth, at constant factor prices (percent) & 7.3 & 6.9 & 6.7 & 6.8 & 6.4 & 6.3 \\
\hline Agriculture (contribution to growth, percentage points) & 0.4 & 0.3 & 0.3 & 0.3 & 0.3 & 0.3 \\
\hline Industry & 3.0 & 2.5 & 2.5 & 2.4 & 2.3 & 2.2 \\
\hline Services & 3.8 & 3.9 & 3.9 & 4.0 & 3.8 & 3.8 \\
\hline Inflation (percent change in Consumer Price Index) & 2.0 & 1.4 & 2.0 & 1.6 & 2.2 & 2.2 \\
\hline Current Account Balance (\% of GDP) & 2.3 & 2.7 & 1.8 & 1.4 & 1.2 & 1.1 \\
\hline Financial and Capital Account (\% of GDP) & -1.6 & -0.8 & 0.2 & -0.3 & -0.2 & -0.1 \\
\hline Net Foreign Direct Investment (\% of GDP) & 1.4 & 0.6 & -0.4 & 0.1 & 0.1 & 0.1 \\
\hline Adjusted fiscal Balance (\% of GDP) a & -0.5 & -2.6 & -3.2 & -3.7 & n.a. & n.a. \\
\hline $\begin{array}{l}\text { Note: } f=\text { forecast. (a) The adjusted fiscal balance adds up the public fin } \\
\text { management fund budget and the social security fund budget. Numb } \\
\text { Source: World Bank staff estimates and projections. }\end{array}$ & te & e & bu & & & \\
\hline
\end{tabular}

Over the medium term, the country's main challenge is the transition to more equitable and sustainable growth. In addition to ensuring macroeconomic stability, a higher share of domestic consumption in GDP is important. Policies oriented towards the reduction in the household saving rate, such as the ongoing pension reform (see Section 3) and changes to the hukou (household registration) system, will be crucial in 
achieving these goals. At the $19^{\text {th }}$ Party Congress, the authorities recognized that policy priorities should focus on the quality rather the pace of growth. In his opening speech, President Xi emphasized the need to "achieve better quality, more efficient, fairer, and more sustainable development". ${ }^{6}$

Besides laying out the country's long-term strategic goals for economic and social development, the $19^{\text {th }}$ Party Congress also emphasized the continuation of structural reforms. Many of the reforms put forward in the $13^{\text {th }}$ Five-Year Plan from 2016, including restructuring SOEs, easing market access, higher efficiency of growth, and higher productivity growth, were reiterated. Attention was also given to reducing overcapacity and leverage, moving China up the value chain of global manufacturing, develop mid- and high-end consumption, innovation, green growth, sharing economy, modern supply chain, human resource services, and environmental protection. More specific policy announcements are expected from three important upcoming events: the Annual Central Economic Work Conference in December 2017 which will set the economic policy priorities for 2018; and the National People's Congress and the National Committee of the Chinese People's Political Consultative Conference in March 2018 which will elect the new Government and announce the major economic targets for 2018.

${ }^{6}$ http://www.xinhuanet.com/english/download/Xi_Jinping's report_at_19th_CPC National_Congress.pdf 


\section{B. Medium-Term Development Agenda}

\section{Budget reform: Recent developments in subnational debt management}

China's fiscal framework is highly decentralized, with 85 percent of budgetary expenditures realized at the subnational level. The Central Government still maintains significant control over subnational "public finance budgets," covering primarily current expenditures, through the determination of taxes, tax rates, and expenditure norms. On the other hand, the larger "government fund budgets," financed primarily from land revenues and devoted mostly to public investment, are determined at the subnational level. Furthermore, in recent years, subnational governments have tapped credit markets quite actively to supplement their public investment finances, mostly through setting up corporate entities of LGFVs.

This highly decentralized fiscal model has played a significant role in China's development success (Qian and Weingast, 1996; Jin et al., 2005). The evaluation and promotion of government officials in China depends greatly on economic performance, particularly with respect to economic growth and public infrastructure. In this context, local governments took strong initiatives to attract investment to their territories and provide requisite infrastructure for rapid growth.

\section{a. Three years of budget reform - initial results for debt management}

A major revision of the Budget Law in 2014 introduced a comprehensive program to bring subnational government finance in line with China's new stage of development. This revision allows local governments to borrow explicitly on budget for the first time under a new debt management framework. Since the global financial crisis, a continued focus at the local level on stimulating investment and growth led to a rapid build-up in LGFV debt. As much of the most essential physical infrastructure has already been put in place, recent local government investments have brought diminishing returns to growth. That has been reflected in lower aggregate returns to capital, i.e. a sharply increasing incremental capital-output ratio (ICOR) (Figure 2.1a). The recent increase in the capital-output ratio can be attributed to an expansion in infrastructure and real estate (Figure 2.1b). Consequently, the 2014 budget reform recognized the need to reorient incentives and constraints of local governments toward a more efficient and sustainable use of public resources.

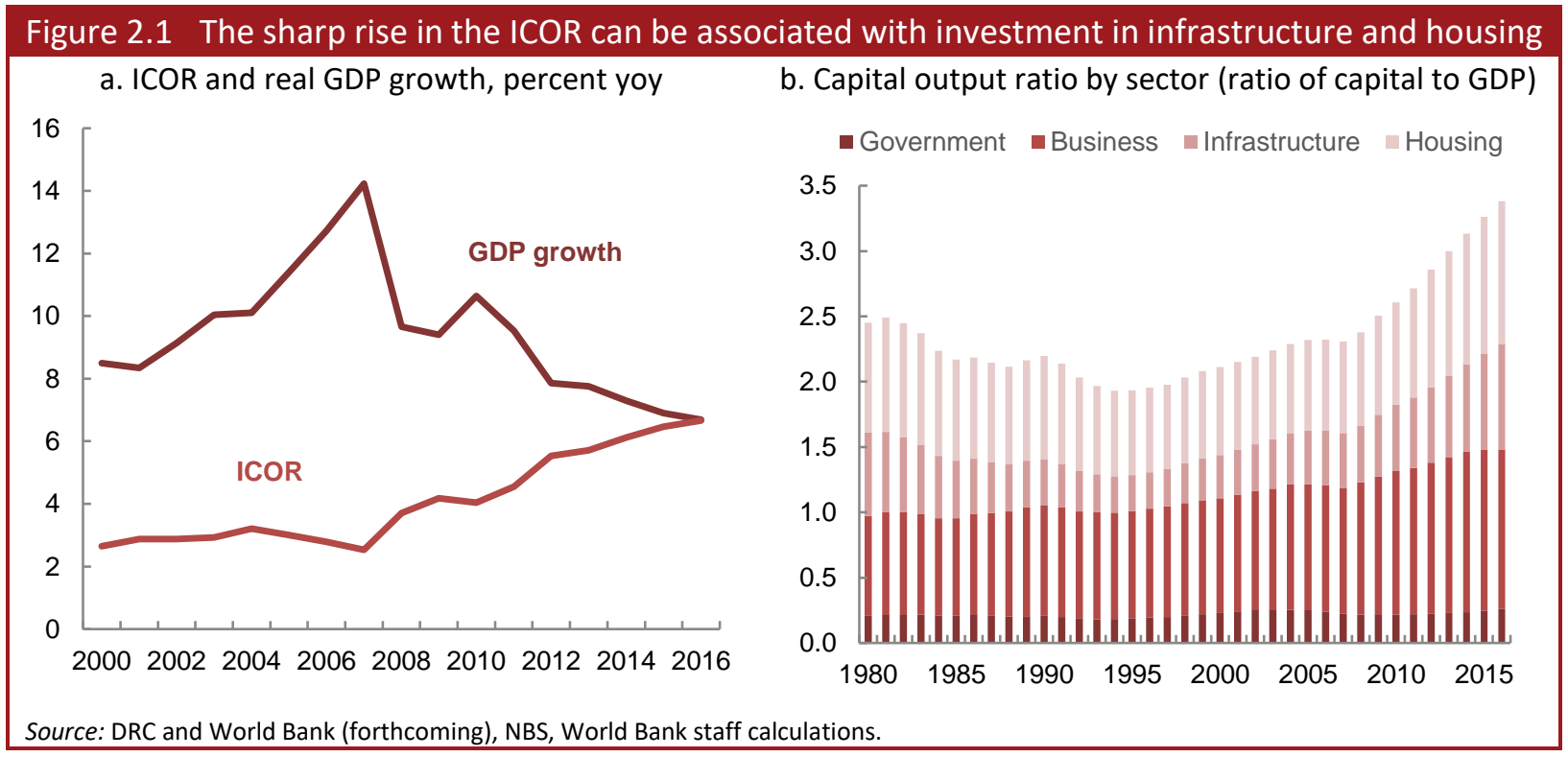


The comprehensive budget reform of 2014 contains many important and self-reinforcing components with regard to subnational debt management, including (a) a shift from off-budget borrowing through LGFVs to explicit local government borrowing through bonds under strict limits; (b) medium-term budget, public investment, and debt sustainability frameworks; (c) early warning systems for monitoring fiscal risks; (d) new standards for accrual-based accounting and financial reporting; and (e) a program to swap implicit legacy government debt in LGVFs into government bonds.

Three years of implementation of this landmark reform have brought important changes to local government budgeting, finance, and debt management. A significant local government bond market emerged very quickly, while the new emphasis on debt management has led to a decline in the share of direct local government debt in GDP since 2014 (Figure 2.2a). Several subnational governments have also made important progress on institutional reforms involving medium-term and more efficient budgetary and public investment planning. Provinces have taken a much more active role in monitoring local governments in their jurisdictions, compelling some of them to implement debt reduction programs. During 2015-2017, roughly 80 percent of the legacy government debt in LGFVs identified in 2014 was swapped into local government bonds.

Given the significant institutional changes embodied in the budget reform, implementation represents a medium-term process that is still on-going. Almost three years of experience in implementation provides some important lessons for the future. In light of this experience, the Government took a number of decisions in 2016 and 2017 in the interest of ensuring a more effective and rapid implementation of the budget reform. The remainder of this section briefly examines some key issues from the experience of 2015-mid-2017, concentrating in particular on debt sustainability and the role of the LGFVs, considers the most recent measures taken by the Government, and identifies a few central challenges going forward.

When the budget reform first began implementation in 2015, the mandate to cease borrowing through LGFVs for public investment presented a great challenge to many local governments. Local governments had been increasingly relying on this borrowing to support high rates of growth in public investment. The prescribed tight new borrowing quotas for local government bonds implied much slower growth in public investment finance for most localities in the absence of LGFV borrowing. Indeed, rates of public investment growth began to slow in early 2015. At the same time, in light of a slowdown in the overall pace of economic growth and some challenges to market confidence, the Government elected to pursue a strongly stimulusoriented macroeconomic stance during 2015 and most of 2016. In this context, restrictions on borrowing by LGFVs were temporarily lifted for existing projects and many localities pursued a public investment stimulus through off-budget "innovative" financing, including private public partnerships, industrial funds, multi-year outsourcing, and borrowing by LGFVs. This occurred in an environment in which off-budget borrowing was no longer included in official public sector accounting or monitoring.

In this context, public investment and associated borrowing by LGFVs did not moderate as anticipated in 2015-2016. While LGFV legacy debt was reduced significantly through the swap program, it grew again as a result of a much larger amount of new liabilities. Based on Wind Info data, which reports the balance sheets of all corporations in China that issue bonds, total liabilities of LGFVs grew at rates well above the average of other corporations (Figure 2.2b). If a correction is made for the bond swap, LGVFs maintained annual growth in total liabilities above 20 percent in 2015 and 2016, compared to average growth of less than 14 percent for other corporations. The share of LGFVs in outstanding debt of the non-financial sector from bank credit and bonds rose from 25 percent in 2013 to 30 percent in 2016, while LGFVs also accounted for a large share of other types of (non-bank) finance as well. 


\section{Figure 2.2 In 2015-2016, local government debt fell as a share of GDP but liabilities of LGFVs continued} to mount

a. Direct local government debt, percent of GDP

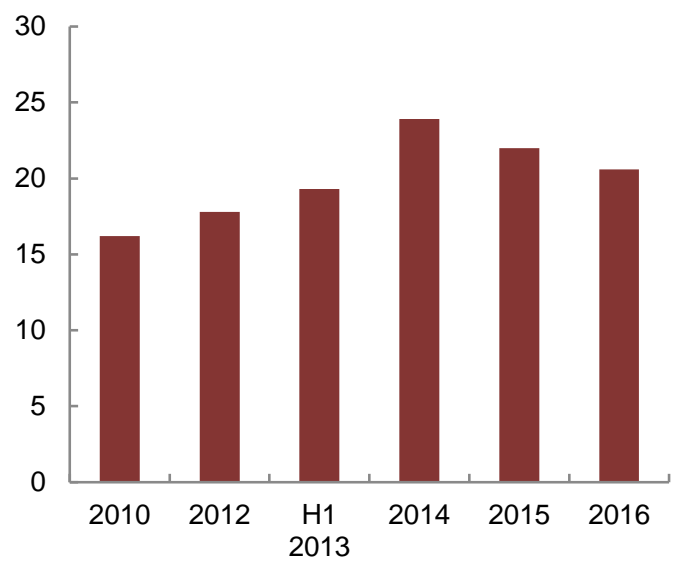

b. Growth in total liabilities, percent yoy

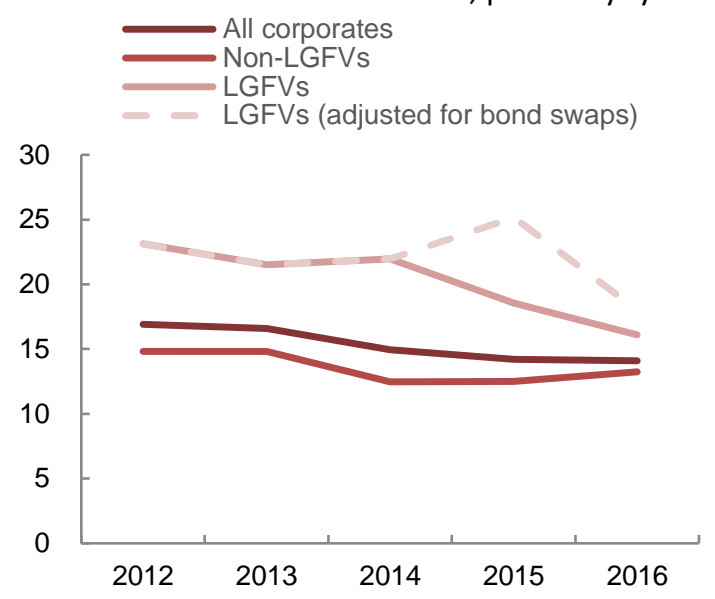

Source: NBS, Wind Info, World Bank staff calculations.

Consequently, despite considerable progress made in 2015-2016 in bringing the stock of direct government debt under control, the rapid continued borrowing by LGFVs during this time made overall public finance in many localities even riskier and more complicated than in 2014. While very incomplete information complicates any assessment of overall local fiscal sustainability, examples suggest that the rate of growth of public-investment related local debt in 2015-2016 presented risks.

Several primary causes of the rapid build-up in LGFV liabilities in 2015-1016 can be identified:

- Local governments commonly felt torn between the goals of full implementation of the budget reform and the priority for a public investment-based stimulus. Strict adherence to financing public investment entirely on budget under the imposed borrowing quotas would have implied a significant drop in public investment growth for many localities.

- $\quad$ Financial markets continued to associate implicit government guarantees with LGFV borrowing, even as growing interest rate spreads in 2016 indicated some perceptions of increased risks.

- New accounting practices and early warning systems excluded LGFV debt. This could have created an impression in some local governments that they have less responsibility for this debt than in the past.

- LGFV debt taken on by local governments in 2015 and 2016 freed up space in LGFVs that was typically filled with more new debt.

- $\quad$ The finances of local government and LGFVs remain intertangled in complicated ways, making an immediate complete separation of their finances quite difficult.

As the situation evolved in 2015 and 2016, the Government became increasingly aware that adjustments would be necessary to alleviate increasing financial risks and ensure a successful reform implementation. In mid-2016, the Ministry of Finance (MOF) launched an initiative to take inventory of potential contingent liabilities emanating from the continued borrowing of LGFVs, as well as from rapidly-expanding local PPP initiatives and other off-budget funds. In October 2016, the State Council issued a "Plan for Emergency Response to Local Government Debt Risks" (State Office Letter No. 88) that required all local governments to set up a Debt Management Leading Group and indicated procedures for resolving cases of financial distress at the local level. The Emergency Response plan acknowledged the possibility of bailouts of LGFVs 
by local governments, but this assistance should not exceed fifty percent of the shortfall in repayment. ${ }^{7}$ The CPC and the State Council also issued a joint opinion that encourages local governments to prepare three-year rolling capital financing plans, and to link these plans to a medium term fiscal framework. ${ }^{8}$

In 2017, the Government launched several initiatives aimed at strengthening the implementation of the budget reform and moving subnational finance to a more transparent and sustainable basis. Among those, Decree No. $50^{9}$ strongly reiterates the requirement that local governments cease borrowing for public investment through LGFVs or other off-budget vehicles. LGFVs are to be transformed into independent state-owned enterprises "as soon as possible" with no preferential treatment or guarantees of any kind from local government. An inter-departmental group at the local level will be responsible for comprehensive monitoring of debt and financial risks to the public sector. Decree No. 50 also strengthens standards for information disclosure by local governments, including detailed information on debt and uses of associated finance. Another initiative, Decree No. 87, ${ }^{10}$ primarily closes several loopholes in procurement regulations that allowed local governments to bypass debt limits through contracts with future fiscal installment pledges.

As a package, the measures adopted in 2016-2017 address directly the key challenges in implementing the budget reform and ensuring the sustainability of local government finances. Decree No. 50 provides a new, strong, and consistent signal from many different governing bodies in Beijing on the future role of LGFVs. The important medium-term goal of a complete separation of government and LGFV finance is clearly recognized. Local governments are now responsible for comprehensive monitoring of financial risks and can no longer assume that they are accountable only for direct government debt.

The new measures appear to already be having a significant impact at the local level. This is supported by anecdotal evidence from discussions with local officials, as well as 2017 data that indicate a significant moderation in the growth of infrastructure investment (Figure 1.1b on page 3). According to Wind Info data, the total liabilities of LGFVs that have issued bonds grew by about 15 percent yoy in the first half of 2017, down from about 20 percent a year during 2012-2016. This slowdown may be more pronounced in the second half of the year, as Decrees No. 50 and No. 87 will be in effect for the entire period. ${ }^{11}$

\section{b. Implementing budget reform will remain challenging but promises major benefits}

A full implementation of the budget reform would result in a more efficient use of public resources, a more sustainable path for subnational debt, and greater public accountability of local governments. Budget reform is also a key component of the general effort to bring growth in credit to the non-financial sector under control and re-allocate investment/credit resources to areas of higher rates of return.

The significant institutional changes embodied in the budget reform will continue to present implementation challenges:

- $\quad$ The macroeconomic context and possible need for a future fiscal stimulus: The public investmentbased fiscal stimulus pursued in 2015 and early 2016 complicated the implementation of the budget reform. In 2017, the strengthening of the world economy and land markets in China provided a more favorable

\footnotetext{
7 State Council, 2016, Section 3.3.3(1).

8 Rolling three-year capital financing plans were first piloted in Hunan Province and Dadukou District of Chongqing Province in 2016 (World Bank, 2016a and 2016b).

${ }^{9}$ MOF, National Development and Reform Commission, Ministry of Justice, PBOC, China Banking Regulatory Commission, and China Securities Regulatory Commission, April 26, 2017, "Notice on Further Regulations on the Borrowing and Financing Activities of Local Governments".

10 MOF, May 28, 2017, "Notice of the Prohibition of Illegal Procurement Activities at the Local Level.

${ }^{11}$ On this note, there are examples of local governments that, in anticipation of Decree 50, frontloaded borrowing by LGFVs in the first half of 2017.
} 
context for reform implementation. However, the future economic environment is uncertain. The challenge is to marry any future need for economic stimulus with the need for sound budget and debt management at the local level. There are two options: First, a future fiscal stimulus in China could place greater emphasis on household incomes and consumption relative to public investment. This would also be consistent with encouraging a re-allocation of investment and credit resources toward servicing that market. Second, if local public investment is to be part of a renewed stimulus, China can learn from the experience of 2015-2016 and avoid giving the impression of an unfunded mandate to local governments, which could result in renewed build-up of off-budget debt. To the degree that such a stimulus involves resources over and above explicit borrowing limits for local governments, the Central Government could provide the needed financing.

- Informational and capacity constraints at the provincial and sub-provincial levels: While the latest round of budget reform initiatives addresses informational constraints directly, overcoming these constraints will be difficult. Provinces face a particularly difficult challenge in monitoring and regulating the finances of sub-provincial governments. Since the provincial government effectively guarantees all local government bonds, it must substitute for the still absent market in evaluating the risks of individual localities. Furthermore, as public finance at the local level has taken a complex form involving multiple onand off-budget sources, provinces do not yet have the full information to assess these risks. The most recent reform measures represent a major step forward in setting up a framework to alleviate these informational constraints and strengthen institutions for debt management and financial risk assessment. The adoption of multi-year local capital financing plans with all sources of finance can be important in providing valuable information, imposing hard budget constraints, and achieving fiscal sustainability. A successful complete separation of government and commercial LGFV finances would simplify enormously the task of risk assessment. Yet, the establishment of an effective fiscal framework of this nature will take time and significant effort. The Central Government can motivate and facilitate capacity building through placing a strong emphasis on budget reform implementation in the performance evaluation of public officials and promoting learning events at which relatively more advanced localities can share knowledge. A second stage of the budget reform could open direct government debt markets at the sub-provincial level, thereby allowing markets to generate important information for the assessment of financial risks.

- The separation of local government and LGFV finances: Untangling the finances of local governments and LGFVs in a meaningful way will not be easy. To the largest extent possible, purely commercial activities could be spun off into fully independent corporations. To the degree that corporate entities continue to perform public functions, the finances of these entities should enter clearly into consolidated government financial reporting and monitoring. Creating and implementing an effective framework for this exercise that does not distort incentives at the local level will certainly be a challenge. So far, the Government has encouraged moving into the budget both the assets and liabilities associated with implicit government debt accumulated in LGFVs during 2015-2017. The next step will be adopting a transparent governance and risk management framework for corporates that perform public functions, while keeping purely commercial entities at arm's length from government.

Addressing the legacy debt overhang: In 2014, the Government developed the bond swap program as an effective means of addressing the debt overhang from the rapid accumulation of debt in LGFVs. Given the pace of LGFV debt growth in 2015-2016, the financial situation of several local governments has likely become difficult, particularly as many of the swapped bonds will soon come due. The Government could examine various options to address this issue in a systematic manner. At the provincial level, governments could identify cases of local governments experiencing inherent fiscal imbalance (i.e. expected revenues and transfers clearly insufficient to shoulder existing debt stock), and prepare for solutions, including adjustment of revenue and expenditure responsibilities, and contingency plans for debt resolution. 


\section{China pensions update}

China's pension system is undergoing fundamental reform that has important implications for social welfare, economic rebalancing, and future economic development. ${ }^{12}$ The government seeks to achieve a pension system that has full coverage, provides basic financial support in old age, and is multi-pillar and sustainable. Much has already been achieved, particularly in vastly expanding pension coverage in recent years. The pension system also faces a number of challenges going forward, including informational and portability constraints owing to the very decentralized nature of the current system, rapid population ageing, ${ }^{13}$ limited benefits for most beneficiaries, a high cost to business from social taxes, and substantial legacy costs. Pension reforms have supported China's socioeconomic transformation and will continue to have important implications for labor market integration and the macroeconomy. This note aims to take stock of the current system and challenges, and highlights potential issues to focus future reform efforts.

\section{a. Pension system design and coverage}

The design of China's pension system provides a broad overarching framework while allowing for substantial variation in parameters according to local economic and fiscal circumstances. The basic elements of the current pension schemes are:

- $\quad$ Urban Worker Scheme (UWS): The design combines a social pooling account with a specific defined benefit (pay-as-you-go) and an individual account funded by individual contributions. It is mandatory for urban workers with employment contracts (excluding public sector workers) and has a contribution rate of 20 percent of wages from employers earmarked to the social pooling account and 8 percent from employees earmarked to the individual account. Migrant workers to urban areas are, in principle, required to participate in this scheme or in RURS (see below), but their participation rates remain well below those of workers with local urban registration (hukou). Retirees receive a basic defined-benefit pension from the social pooling account and additional benefits from individual account accumulations.

- $\quad$ Public Sector Scheme (PSS): The PSS is for civil servants and employees in public sector units (PSUs). It was non-contributory until recently. In 2015, a national framework for workers in the public sector was implemented. The first PSS component is the same as the UWS and the second component is a compulsory occupational pension scheme, which has a contribution rate of 8 percent from employers and 4 percent from employees. This means that total contribution rates are 28 percent from employers and 12 from employees, respectively.

- $\quad$ Rural and Urban Resident Scheme (RURS): The RURS was introduced for rural residents in 2009, extended to urban residents in 2011, and merged in 2015, ${ }^{14}$ even though administration is still fragmented. It is voluntary with a modest minimum annual contribution required (as low as RMB 100 per year, depending on the locality) which is matched by at least 30 percent by local authorities. Contributions are held in what are meant to be funded individual accounts. After 15 years of contributions, workers who reach the retirement age of 60 are entitled to both a flat monthly pension (the "basic benefit" - currently a minimum of RMB 70 per month nationally but varying by locality) as well as an annuity based on the accumulation in the individual account. The basic benefit is financed at the national level in poorer provinces, with the financing shared between national and subnational authorities in better-off regions.

- $\quad$ Voluntary enterprise annuity and individual pension savings: The voluntary Enterprise Annuity (EA) scheme was established in 2004 as a regulated and supervised framework for voluntary supplemental

\footnotetext{
12 The authorities have been working on a comprehensive pension reform proposal, which are expected to put it in place in 2018.

${ }^{13}$ For details on China's demographic transition in a comparative EAP perspective, see World Bank (2016).

14 There are non-contributory social safety net (dibao) arrangements provided on a local level to the elderly in poor households and in some cases, supplementary non-contributory benefits for the poor elderly.
} 
pensions savings for private sector workers. Only large SOEs or large private sector enterprises have established EAs for their employees. There are also private voluntary pension arrangements offered by financial institutions apart from the EA arrangements, but take-up has been very limited.

The authorities are currently considering financing the individual accounts in the UWS and PSS on a pay-asyou-go basis. In practice, many UWS accounts have been empty or only partially filled, thereby requiring de facto pay-as-you-go funding. In 2017, a joint regulation of MOF and the Ministry of Human Resources and Social Security (MOHRSS) established an administratively determined annual rate of return on IAs in the UWS and PSS. ${ }^{15}$ The interest rate is determined mainly by such factors as employee wage growth and the fund balance and should not be lower than the national bank time deposit rate. Although this formulation centralizes rate determination, it does not ensure adequacy of benefits, as rates of return on bank deposits in China have been historically far below wage growth and this is likely to continue in the years ahead.

Pension coverage is now relatively high for a country at China's income level. The number of contributors reached 634.1 million in 2016, accounting for 64.0 percent of working aged population and 78.6 percent of the labor force (Table 3.1). Pension coverage of the UWS for migrant workers has gradually increased over the past decade but remains challenging. ${ }^{16}$ At the end of 2016, 59.4 million rural migrant workers were enrolled in the UWS, accounting for 35.1 percent of total migrants outside their hometowns. About 76,300 enterprises have established voluntary Enterprise Annuity schemes covering 23.3 million workers or 2.9 percent of total labor force.

\begin{tabular}{|c|c|c|c|}
\hline & Contributors & Pensioners & Total \\
\hline Urban worker scheme (a) & 252.4 & 90.2 & 342.6 \\
\hline Migrant workers & 59.4 & 0.0 & 59.4 \\
\hline Voluntary enterprise annuity & 23.3 & 0.7 & 24.0 \\
\hline Public sector scheme (b) & 25.9 & 10.8 & 36.7 \\
\hline Rural and urban resident scheme (c) & 355.8 & 152.7 & 508.5 \\
\hline Total $(a+b+c)$ & 634.1 & 253.7 & 887.8 \\
\hline
\end{tabular}

UWS replacement rates-a measurement of pension benefits over wages at retirement or the current average wage--have fallen below those anticipated when the scheme was established in 1997 and RURS benefits are often only a fraction of the poverty line. Across schemes, the replacement rates of civil servants and most PSU workers have historically been well above those of other urban formal sector retirees. In 2013 , civil service retirees had an estimated average replacement rate of 89 percent as compared with a 45 percent average in the UWS. In 2015, the State Council expanded the investment options for pension funds to include debt and equity market instruments, which could improve returns and, therefore, the possibility to increase pensions. To access the additional investment classes, provincial pension funds must invest through the National Social Security Fund (NSSF). To date, 13 provinces have entrusted UWS pension reserve management to NSSF, with Shandong, for example, placing around half its pension assets with NSSF in 2015 and Guangdong around one third in 2012. Recent performance of NSSF and provincial pension funds suggests that this should improve returns, though with additional volatility.

\footnotetext{
$15 \mathrm{MOHRSS}$ and MOF, "The approach on unifying and standardizing the book-keeping interest rates for individual accounts of the Urban Worker Pension Scheme," April 13, 2017.

${ }^{16}$ See Giles at al. (forthcoming) for estimates based on household survey data and a useful discussion of the drivers of low migrant participation in UWS.
} 


\section{b. Reform challenges include coverage, system integration, and financial sustainability}

To achieve a full pension coverage by 2020, in 2014 the authorities launched a policy initiative to extend pension coverage to the 21.4 percent of the labor force that is outside the existing pension system. Since 2014 the authorities have been collecting information on pension enrollment through the issuance of social insurance cards with the intention to use the database to target those who do not participate in any pension scheme.

High UWS contribution rates and minimum contributions make participation unattractive for many employers and workers. China's current UWS contribution rates are the highest in the region (around 40 percent of salary if all social insurance contributions are considered including health insurance, maternity, work injury and unemployment insurance), and high by global standards. ${ }^{17}$ These high rates provide incentives for employers to under-report wages or recruit workers through labor dispatch services to avoid payroll taxes. In addition, extending the existing UWS to cover more workers would increase pension revenues temporarily but will generate higher pension liabilities in the long run.

Extending RURS pension coverage also faces challenges. Contribution rates are generally low enough not to deter coverage in the RURS. However, low levels of anticipated benefits may deter some workers from participating, particularly those more than 15 years away from retirement. ${ }^{18}$

The authorities are aware that an integrated pension system could facilitate labor mobility. Most pension rights accrued in China are not portable between provinces and across cities. This is an acute problem in China with its high level of labor mobility and migrant workers. ${ }^{19}$ Portability of pension rights is vital to ensuring a flexible labor market and worker welfare. Since 2009, China has issued policy directives supporting the transfer of pension rights and benefits across space and between schemes. However, there remains a range of implementation challenges in making pension portability operational. In many provinces, information systems are not yet sufficiently inter-operable to make the sharing of pension records smooth, and mechanisms for transferring balances are still evolving.

Administration of all schemes remains highly decentralized and greater centralization is a reform objective. Historically, UWS revenues were pooled at a prefectural level or lower, resulting in widely varying financial balances and contribution rates across space. The national policy direction is to move towards national pooling of at least part of contribution accumulations over time. Only a few provinces ${ }^{20}$ have so far achieved full provincial level pooling and others have partial pooling through adjustment funds. For the RURS, account and fund management remains at a county and district level, though there is significant financial support from central and/or provincial authorities for payment of pension benefits in many provinces.

Diverse and decentralized administration of pensions and social insurance remains a major challenge. Around half of provinces collect contributions through the tax administration, while the rest rely on local Departments of Human Resources and Social Security to collect. Information systems underpinning collections and pension record-keeping usually lack inter-operability even across prefectures within provinces, let alone across provinces, despite efforts by MOHRSS to promote common national IT and data standards in recent years. As a result, data exchange and sharing across space is limited, which adversely affects portability of pension records.

\footnotetext{
17 UWS minimum contributions are 60 percent of the provincial average wage.

18 The scheme has an effective feature whereby adults who contribute to the scheme can use their participation as a basis for eligibility for their elderly parents.

${ }^{19}$ Around 169 million workers live outside their hukou jurisdiction.

20 Beijing, Shanghai, Tianjin, Chongqing, Shaanxi, Qinghai and Tibet. See the World Bank Report (2013).
} 
Contribution rates have varied across China, although there have been efforts towards harmonization. This has included contribution rates to the UWS (often within as well as across provinces) and the contribution and amount of government matching contributions to the RURS. Since 2015 the authorities have reduced UWS contribution rates to ease the burden on enterprises: employer contribution rates to the social pooling accounts were limited to no more than 20 percent, while those already at 20 percent reduced to 19 percent ${ }^{21}$. Further reductions in contribution rates will drive up the required government subsidies, in large part because the legacy costs of pre-reform pension benefits are financed by contributions.

The fiscal challenge of China's pension system is substantial, reflecting both current parameters and legacy issues. Overall, the financial balance of the UWS has been worsening in recent years and there has not been a systematic actuarial assessment of financing pensions in the future even in the midst of a rapid aging process. ${ }^{22}$ The annual deficit of UWS increased from 0.6 percent of GDP in 2010 to 0.8 percent of GDP in 2014. More importantly, projections of the growth in the number of retirees relative to contributors suggest a serious challenge for the sustainability of the pension system and potentially a serious fiscal burden. Generally, countries undertake an in-depth actuarial assessment including long-term financial projections to discern changes in design, parameters and/or qualifying conditions to ensure that that the Government can finance pension commitments.

The financial position of pensions varies significantly across provinces, reflecting diverse demographic and fiscal conditions. Most provinces face UWS deficits, while several provinces with a younger population and rapid economic growth, such as Guangdong, have significant surpluses (Figure 3.1). The variability in financial balances reflects several factors, such as the system dependency ratio (the ratio of contributors to beneficiaries) which ranges from as high as 10:1 in Guangdong to as low as 1.3:1 in Heilongjiang, with the national average declining from 3.1:1 in 2012 to $2.9: 1$ by $2015 .{ }^{23}$

\section{Figure 3.1 UWS accounts were in deficit in many provinces in 2014}

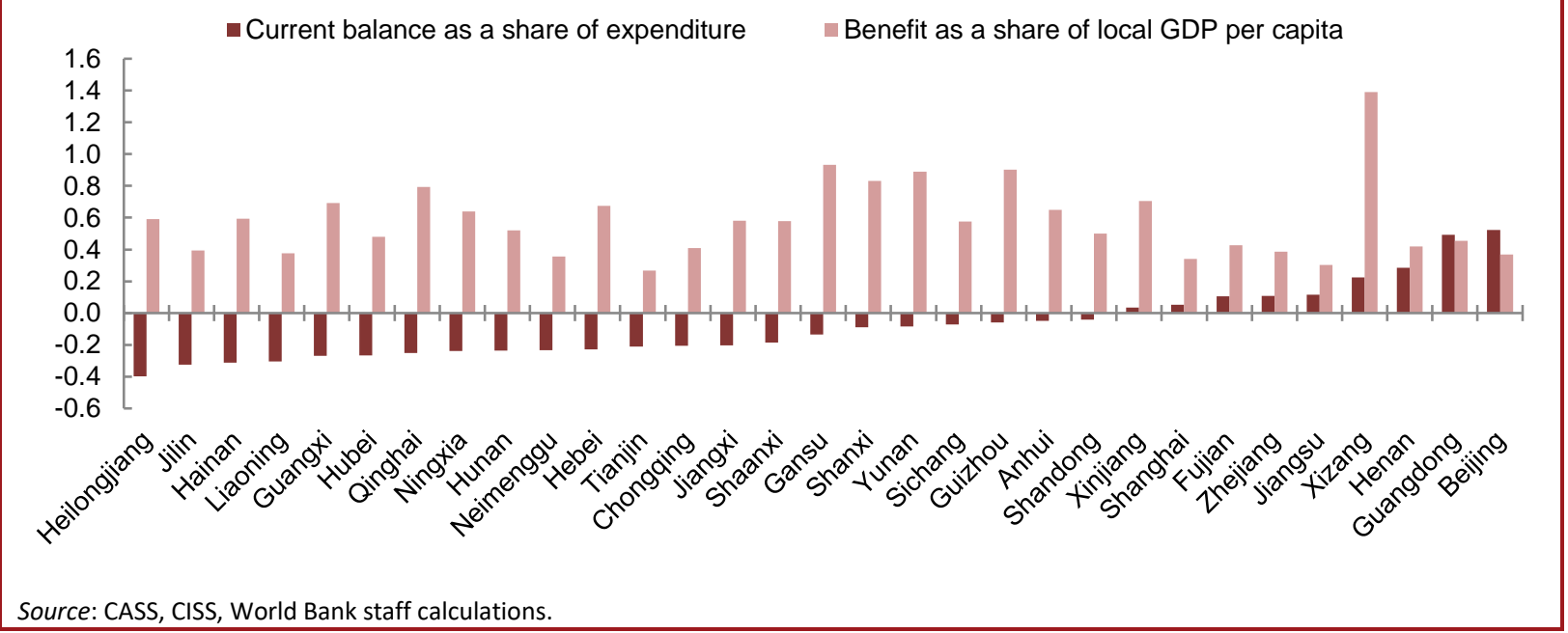

Raising pension benefits can increase the degree of adequacy and might be able to address the equity issue, but would likely require greater outside financial support to ensure sustainability. For UWS, China has continuously increased their pension benefits over the past 14 years, but the adjustment of pension benefits is not based on a formal indexation mechanism and not informed by the estimates from the

\footnotetext{
21 Provided that they have at least 9 months' worth of pension payments as a surplus.

22 Indexation of pension benefits has also not been done on the basis of actuarial projections.

${ }^{23}$ China Pension Report, 2015.
} 
actuarial projection. The more fundamental adequacy challenge is the very low level of benefits for the RURS, which cannot be addressed without either significantly higher budgetary subsidies to finance the basic benefit or higher contribution from workers in the voluntary scheme.

A key source of financial pressure is low UWS retirement ages--60 for men, 55 for some white-collar women, and 50 for other women. Actual retirement ages are often 2-3 years lower due to early retirement rules. Given China's life expectancy at age 60 (across provinces from around 23 years to as high as 27 years), China's official retirement ages are remarkably low and well below the OECD average and those of East Asian countries with aging populations. The difference between the legal retirement ages for men and women (5-10 years) is also out of line with international practices, with the average gap across OECD countries around one year and falling, and comparator EAP countries such as Japan, Korea, Philippines, and Singapore having unified retirement ages between genders. Increasing the retirement age to 65 for both men and women would significantly improve the financial sustainability of the UWS.

The most significant challenge to pension finances is the legacy costs of the pre-reform UWS. Reduction of benefit commitments between generations create legacy costs which are still payable to older generations. These costs are a key driver of the high contribution rates in China, as the pensions of pre-reform pensioner cohorts are financed from current contributions. While the authorities recognize this issue, there does not seem to be an agreed-upon method for calculating legacy costs, nor agreement on a means of financing such costs over time. Legacy cost estimates vary between MOHRSS, MOF and NDRC, ranging from RMB 1.4 trillion to 6.3 trillion, with World Bank estimates even higher. ${ }^{24}$

\section{c. Looking ahead}

The challenges of the pension system are well understood by policymakers and the broad directions of future reforms are clear. As noted, the authorities are currently developing a comprehensive pension reform strategy. A more sustainable pension system with an automatic balancing mechanism and adequate pension levels could reduce precautionary savings, boost domestic consumption, remove fiscal pressure, and promote macroeconomic stability. Key issues include:

Moving toward a single, unified, and more centralized pension system represents a key reform goal that can multiple positive benefits for China's economy. These include bolstering consumption-driven economic growth, facilitating labor migration to areas of higher productivity, and possibly reducing the current high burden of social taxes on the cost of doing business through budgetary transfers to a unified pension fund. Achieving a national pooling of revenues and expenditures and centralization of pension administration will require a medium-term approach in stages. Achieving more widespread pooling at the provincial level could be an important intermediate step. Partial pooling through the employment of adjustment funds might be useful as a transitional arrangement, but should not substitute for the crucial goal of moving toward national pooling. Harmonization of contribution rates, rates of return on individual accounts, and indexation parameters will also help. Over time, consideration should also be given to standardizing the channel for collection of social insurance contributions, which could also streamline data sharing and monitoring of both pension and income tax finances at the subnational level.

Financial sustainability hinges on implementing parametric reforms. Measures to consider include: (i) initiating a gradual increase in retirement ages (by, say, 6 months per year) and unifying them for men and women; (ii) establishing a uniform framework for automatic pension indexation; (iii) lengthening the reference period of wages used in determining the UWS basic benefit; and (iv) introducing a framework

\footnotetext{
${ }^{24}$ Assuming a 25 percent forward pension contribution rate, World Bank estimates vary between 44 and 56 percent of GDP, the bulk of it in the UWS for financing the entitlements of "old men" and "middle men" (Dorfman et al., 2013).
} 
for automatic adjustments in annuity factors for both the UWS and RURS, given growing life expectancy at retirement age.

Developing a financing strategy for UWS legacy costs is vital to make the contributions sufficiently affordable to ensure broad worker coverage. There have been many ideas as to possible financing sources including the NSSF, SOE assets, special long-term bonds, and general revenues on a central and local level. A recent policy initiative calls for transferring 10 percent of SOEs equity into the social security funds, ${ }^{25}$ which will be helpful to address the shortfall of pension funds and the issue of fiscal sustainability.

More effort and innovation are needed to broaden coverage to migrant workers, the most challenging group to reach. Part of the approach will be stronger enforcement, but improved incentives to participate and sanctions for non-compliance are also needed. Evidence suggests a strong correlation between pension participation and whether or not migrants have written labor contracts (Giles et al., forthcoming). Reducing UWS contribution rates, such as through financing legacy costs outside the UWS scheme, could also be considered.

25 State Council, "Notice on the implementation plan of transferring state-owned capital to increase social security funds," November 9, 2017, released by MOF on November 18, 2017. 


\section{References}

Development Research Center (China) and World Bank, "China: New Drivers of Growth," forthcoming in 2018.

China Academy of Social Science (CASS) and Center for International Social Security Studies (CISS), 2015, "China Pension Report 2015," B. Zheng, Ed., P.R. China: Economy and Management Publishing House.

Dorfman, M. C., R. Holzmann, P. O'Keefe, D. Wang, Y. Sin, and R. Hinz, 2013, China's pension system: A vision, Washington, DC: World Bank.

Giles, J., X. Meng, and S. Xue, "Does information influence the decision of rural migrants to participate in social insurance?," forthcoming.

Herd, R., 2017, "Estimating capital formation and the capital stock by economic sector in China," mimeo.

Jin, H., Y. Qian, and B. Weingast, 2005, "Regional decentralization and fiscal incentives: Federalism Chinese style," Journal of Public Economics, 87:2, pp. 354-358.

Qian, Y, and B. Weingast, 1996, "China's transition to markets: Market preserving federalism, Chinese style," Journal of Policy Reform, 1:2, pp. 149-185.

World Bank, October 2017, "East Asia and Pacific economic update: Balancing act," Washington, DC: World Bank. 